\title{
The Dramatic Form of Ambition in Early Nineteenth-Century France
}

\author{
Javier Moscoso, Institute of History, Spanish National \\ Research Council (CSIC)
}

It is well known that in the first years of the nineteenth century, theatre and dance were employed as part of the moral treatment for the mentally ill. ${ }^{1}$ The use of this kind of entertainments was common in early asylums. According to the historical account provided by Jean-Étienne-Dominique Esquirol, François Simonet de Coulmier, then director of the asylum of Charenton, turned the infirmary into a ballroom and transformed one of the hospital rooms into a space suitable for theatrical performances. The renovation included, along with the stage and the stalls, a pit for the orchestra. ${ }^{2}$ Convinced that theatre could cure madness, and thrilled with the success that this kind of performances began to have among the Parisians, Coulmier also had a box built for his most notable guests. ${ }^{3}$ The chronicles of the hospital echoed that the most famous of its inmates, the Marquis de Sade, helped organize these shows, which were joined by dancers and actresses from the city. For some years, the Parisians flocked to see the prodigious effects of this extraordinary cure. Though the system was never able to cure anyone, it did scandalize many. ${ }^{4}$ Baron Collins, for example, who visited the asylum at that time, was surprised not only by the intimate relationship between Coulmier and Sade but also by the circumstances in which the performance took place. He was convinced that music excited the passions of the insane, encouraging lascivious postures between hysterics and nymphomaniacs. ${ }^{5}$ At the same time, he found it somehow impudent to turn the malady of some into the entertainment of others. Dr Alexandre Auguste Millet also commented in the same vein that Bicêtre's unfortunates were really worthy of compassion and that

Cultural History 8.1 (2019): 7-23

DOI: $10.3366 /$ cult.2019.0184

(C) Edinburgh University Press

www.euppublishing.com/cult 


\section{Cultural History}

every time visitors threw coins at the guards, inmates were transformed into fierce brutes. ${ }^{6}$

Pierre-Paul Royer, better known as Royer-Collard, appointed chief physician at Charenton in 1805, expressed his doubts regarding the so-called Thursday Feasts, and the authorities finally banned theatrical performances on 11 July 1811. Esquirol's point of view, however, never reached such a degree of dogmatism. He was convinced of the usefulness of these treatments provided that some form of play or music, and even the spectators, could be specifically selected for each patient. ${ }^{7}$ The same dispute took place in Bicêtre in the late 1830s. Despite the criticism, François Leuret set up his own theatre, which began operating on 1 October 1841. Although it was cancelled shortly afterward, music and theatre occupied, along with cold showers and other sublime remedies, a prominent place in the moral treatment of the insane. According to the medical authorities, music was capable of fixing the attention through sweet affection and pleasant memories. ${ }^{8}$ Dr Marc Auberthie-Lamalethie recognized it as one of the most powerful and energetic means that could be employed to exalt the imagination, to bring maniacs into a state of enthusiasm and inspire in them a boundless confidence. ${ }^{9}$ For this young doctor, as later for Leuret, music and theatre were able to revive courage and renew strength.

In this article I deal with the spectacle of madness from a different angle. The emphasis will not be on music and play but on another kind of theatricality, an expression that I have borrowed from the anthropology of experience. ${ }^{10}$ My intention is to explore the rhetorical elements that make certain forms of experience possible. The spectacle of suffering, so much present in the asylum, does not refer here to the field of the visual but to a different form of representation by means of which an emotional experience could be turned into a story. By looking at the way in which madness was given the form of a social drama, I intend to suggest a new way to look at the history of the passions that focuses on the preconditions rather than on the results. The pathologization of passions in general, and of ambition in particular, required a new observational and visual regimen in which certain passionate states could be regarded as vehement or delirious. The transformation of emotional symptoms into clinical signs required the mobilization of many elements, including the attentive observation of the inmates, their gestures and, of course, their expressions. In the clinical histories written by doctors, readers have the (false) impression of encountering directly the unfortunates whose lives and conditions were reported in great detail. In many cases, the configuration of the clinical record acquires the form of a short novella. In some others, 


\section{Ambition in Early Nineteenth-Century France}

in which those who are mad are quoted directly, we are tempted to believe that we may hear their inner voices. In both cases, there is little doubt that the cultural and medical configuration of madness requires not just actors and directors but also a plot, a stage, costumes, props, scenography and, of course, an audience. ${ }^{11}$ From this point of view, there is not so much difference between the spectacles of madness performed at Bicêtre or Charenton and this other form of visual narrative that has been rightly compared to an opera libretto. ${ }^{12}$

To explore these narrative forms, I examine in detail one of the clinical cases reported by Leuret, chief physician for the mentally ill at the prison of Bicêtre. This gives me the opportunity to look at the elements of theatricality included in the clinical reports, but also at the performative nature of emotional states. I claim that the interplay between emotions and clinical conditions was at the core of the pathologization of passions that took place in the early nineteenth century. For one thing, the clinical cases used a notorious variety of rhetorical elements designed to persuade lay readers and experts alike of the verisimilitude of the cases. The way in which inmates were portrayed and their histories told formed part of the transformation of emotional expressions into clinical signs, but also served as a way of vindicating different forms of treatment. The confrontation of the clinical records and the archival material also gives us the opportunity to explore further the way in which emotions were rendered, registered, repressed and, eventually, 'cured'. Since the case that I will be exploring refers to a particular passion, we will have to give a very short account of how this passion was understood and valued at the time.

\section{A case study}

According to the medical history written by Leuret, published in 1846 , Monsieur Nicolas was an educated man, of a nervous temperament and delicate and fragile constitution. ${ }^{13}$ At the age of thirty he had not yet been able to reach a position that guaranteed his own sustenance. Yet he had a cultivated intelligence, spoke several languages and wrote easily in both prose and verse. Leuret describes him as a whimsical person, dominated by his passions, always willing to find reasons to blame others rather than accept responsibility for his own improvidence. His erratic behaviour had led him to the edge of destitution. He seemed to have given himself to overeating and had also 'abused the institution of marriage' (sex), even if his physical debilitation made absolute continence advisable. His admission to Bicêtre was not his first stay in a similar establishment. On the contrary, Nicolas had already been in an 


\section{Cultural History}

asylum in the provinces and had remained there for a couple of years, first as a resident and later, against all odds, as deputy director! ${ }^{14}$

As in many other similar cases, the writing of this medical history requires many rhetorical devices and narrative strata. To begin with, the way in which the patient portrayed himself differs from the doctor's judgement about his physical features, his manners and his gestures. During their first meeting, Nicolas answered all questions willingly, explaining in a simple and elegant manner that he had come to Paris with a government mission. He claimed that he had been betrayed and, as result of this, had been beset by debts that his parents refused to pay. His arrest had taken place at his own initiative. He had entered the guard office and said, 'Arrest me! I have no means of subsistence.' He was then led to the prefecture, from where he was soon moved to the section for the mentally ill. He had clearly preferred prison since his arrest was intended, as he argued, to humiliate the pride of his parents and to punish them for their greed.

Leuret, one of the leading disciples of Esquirol, listened to him with calm and gentleness. Although the patient seemed confused, his facial expression was acceptable, and his manners appropriate. He was calm and relaxed. Only occasionally had he passed, almost without transition, from anger to laughter. Later that day, however, Leuret was informed that the inmate had entered a true outbreak of furious mania. Apparently, his speech became senseless and his face reddish. He was in such a violent state that the guards restrained him. Nicolas, who spoke with vehemence, expressed himself in perfect French, and sometimes in Italian, always keeping the inflection of his voice in harmony with the meaning of his words. When Leuret entered the room, he was reporting the story of his life, an unfortunate and sad story, composed of 'broken hopes, shattered expectations, neglect of care, deprivation, poverty, unjust detention, brutality and violence' ${ }^{15}$ In the doctor's opinion, a horrible delirium was exalting his imagination. Nicolas specifically complained about the treatment he had received from two guards at the hospital, who, in the doctor's opinion, were absolutely unable to have caused him any kind of outrage. He wanted to kill them and said: 'Che piacere!! vedere questi duo corpi morti e ballare! [What a pleasure, to see these two dead bodies, and dance!] Io farò una vendetta terribile ... [My revenge will be terrible]. Death to the guard; death to the doctor. I'll be out of here alive or dead. I do not know.' And he kept repeating 'Io farò, etc' with a threatening and broken voice.

It might be worth noting that Nicolas does not seem to have been mentally ill. He had had himself arrested as a kind of revenge. He believed that he was entitled to favours that he had not received. 


\section{Ambition in Early Nineteenth-Century France}

He described his fate in terms of broken promises and shattered expectations. He claimed that he had been betrayed - by his parents, by his partners, by his friends. Even if the word ambition was never mentioned in this clinical history, only these broken expectations had made the whole situation possible. Like many other French citizens at the time, including Leuret himself, Nicolas was not willing to accept that his conditions of birth should determine his economic and social fate. His attitude was fed by an inflamed passion triggered by what Alexis de Tocqueville called the 'democratic revolution'. 16

\section{The cultural form of ambition}

In contrast to the brief moment of splendour that ambition experienced in the eighteenth century, the early nineteenth century witnessed an unprecedented demonization of this passion. The Europe of the Restoration promulgated a new ethical code based on the restriction of desires. Disguised with different names, hidden under many masks, almost always linked to ignoble vices or immoral sins, the immoderate wish for honour or wealth became identified with a social danger that had to be avoided and fought against. ${ }^{17}$ According to François-René de Chateaubriand, it was ambition that had allowed many of his compatriots 'to move from mediocrity to importance, from importance to foolishness, and from foolishness to ridicule'. ${ }^{18}$ From a purely quantitative point of view, this passion became an epidemic. Its physical and political effects, its influence in the configuration of the here and now, were mentioned everywhere: from autobiographies to obituaries, from medical records to treatises on public and military hygiene, from cookbooks to religious sermons. The moral treatises of the time discussed it at length. One of the most important was published by the physician Jean-Baptiste-Felix Descuret in 1841. Drafted based on a wide variety of medical cases and medical records, this 'grammar of the human passions' aimed to investigate the role played by emotions in the outbreak of mental illnesses and physical ailments. The topics of the book included those emotions described by the great compendia of antiquity, such as greed, anger and pride, but also other emotional states resulting from moral relaxation, like gluttony, sloth and licentiousness. Descuret's obsessive desire for completeness also led him to the study of love and longing, collecting and, of course, ambition. For Descuret, the immoderate wish for distinction was not just one cause among others but the leading force that explained the events of 1789, the outcome of the Terror and the delirium of dictatorship - a point of view shared by many other authors. Germaine de Stäel, for example, in her small treatise on the passions, published in Lausanne in 1826, made similar remarks. 


\section{Cultural History}

She considered ambition the true obstacle to the well-being of nations. ${ }^{19}$ For Jean-Louis Alibert, a doctor from Montpellier, ambition was an unreasonable envy. It was a passion composed of pride and obstinacy; a violent and continuous wish to rise above others, including the ruin of others; and an immoderate thirst for glory, domination, greatness and honours, as well as wealth. ${ }^{20}$ Those who suffer from its most dreadful consequences, wrote Etienne Tourtelle, another Montpellier doctor, always want to go beyond their present pleasures, always 'wander between fear and hope'. ${ }^{21}$ For Descuret, who had witnessed the epidemic of cholera in Paris in 1832, ambition could be compared to that disease. It was a cancer that fed on its victims' desires and expectations, often causing a fatal despair and destroying and burning the body.

In any of its different forms and expressions, ambition led to ruin, madness or dishonour. For Tocqueville, Josep de Maistre and Edmund Burke, neither the Revolution nor the empire could be understood without that 'mania of elevation, that equalitarian passion', as Tocqueville put it. ${ }^{22}$ For the abbé Augustin Barruel, the 'Revolutionary conspiracy' had relied on the capacity given to the third estate's members to gratify their pride and their vanity. ${ }^{23}$ In Descuret's account, he also observed that eighteen members of the National Convention were guillotined, three committed suicide, eight were deported, six incarcerated, twenty-two accused of different crimes and four taken to be lunatics. One of them, Marie-Jean Hérault de Séchelles, had written a book titled Theory of Ambition around 1788 in which he had already argued that the number of people afflicted by this passion had never been so high. ${ }^{24}$

This connection between immoderate passions and political events was also one of the most remarkable features of the new asylums for the mentally ill. ${ }^{25}$ At the very heart of the new clinical discourse, passions and mental illness went hand in hand. 'Those who suffer from ambition are like those who suffer from delusions,' wrote Alibert. ${ }^{26}$ During the first decades of the nineteenth century, Descuret observed that a majority of those admitted to the new asylums for the mentally ill had problems related to ambition in one way or another. Many of the medical observations in the archives referred to similar cases: Anne-Antoinette-Charlotte Blottefière, a court woman from Versailles, came to Charenton in July 1802, suffering from 'ideas of grandeur', and remained in that institution for eighteen years. On 14 December 1819, Joseph Heim was diagnosed with ambitious delirium without agitation. He died two years later. ${ }^{27}$ On New Year's Eve in 1819, M. Schuller, age fifty-nine, a native of Colmar who had left his home earlier that year and had ever since experienced a state of sadness, along with fixed and 


\section{Ambition in Early Nineteenth-Century France}

violent ideas, also entered the hospital. His delirium was that he thought he could open the most beautiful brasserie in Europe. He died one year later, uncured. ${ }^{28}$

Though some of the inmates may have had highly extraordinary delusions, the condition of many had resulted from common affairs and emotional expectations. François Geoffroy, for example, was an army musician who entered the asylum as a consequence of his comrades' humiliations. Grégoire Delaroche, a student at L'École polytechnique who had been attacked by his superiors during a trip to Metz, came to believe that he was the author of nature, able to throw thunder and kill all his enemies. M. Dechatelard almost never talked to anyone. He liked taking long walks around the gardens of Charenton, an institution he thought he owned. ${ }^{29}$ M. Maurel thought he was a French general; François Camiat pretended to be the son of Louis XVI and later claimed to be Jesus Christ. François Brosard claimed to be the oldest person of the asylum: he was 100,000 years old, a delirium that had begun after the death of his beloved wife. ${ }^{30}$

Though much has been written about these patients, their social and geographical backgrounds have usually been neglected. We know, however, that most patients came from rural areas or small cities. In his tourist guide to the Alps, François Emmanuel Foderé, a doctor and botanist, the chair of public hygiene at the University of Strasbourg, explained how, during the second half of the eighteenth century, all small cities in France had 'la manie de la noblesse, and this passion was carried so far that any craftsman who had managed to have a thousand crowns income, aspired to become earl or baron' ${ }^{31}$ In his Treatise on Medicine of the Cities and the Countryside, Jean-Marie-Placide Munaret also explained how self-love recruited its victims from the very bottom of the provinces. 'It is there that professionals of any age ... imagine that they are appointed knights of the Legion of Honour, or members of two or three academies. ${ }^{32}$

There is nothing surprising in this contrast between the pure life of the countryside and the emotional dangers of the city. Following the teaching of his master, Philippe Pinel, Esquirol explained that while in the countryside most mental illness originated from simple passions and circumstances - such as love, anger and domestic quarrels - in cities and urban centres madness seemed to be the product of the wounds of self-esteemed, truncated ambitions and unexpected changes of fortune. Along with the natural passions - those determined by the natural desire for survival, reproduction and perpetuation of the race, that is to say, along with those passions linked to the instincts and natural desires - there were some other passions that many doctors called, 


\section{Cultural History}

following a long tradition that originated in classical antiquity, factices, literally, artificial or fictional passions. These were the sort of emotions that lay at the very origin of the contemporary derangement of reason: ambition, greed and love of glory, of celebrity or self-esteem. ${ }^{33}$

\section{Symptoms and signs}

The case of Nicolas is also telling in this regard. Like many others before him, he came from the French provinces thinking that he deserved greater honours and better rewards. Despite the essential difference that placed Nicolas and Leuret on opposite sides, the doctor's description of the inmate's personality does not differ much from the description of Leuret provided by his biographers. Charles Hequet, for example, portrayed him as an indomitable man of a sanguine nature, enslaved by an idea. ${ }^{34}$ Ulysses Trélat also began his obituary by referring to what he called the 'virtuous perseverance' of his colleague, who seemed to have the imperative need to devote himself with all his might to the service of humanity. ${ }^{35}$ Both biographers described the doctor as a man who, starting from humble beginnings, owed only to his efforts the brilliant position he had reached by the end of his life. Many other circumstances exemplify well the elements underlined by historian of science Jan Goldstein with regard to the professionalization of psychiatric medicine in the early nineteenth century. ${ }^{36}$ Concerned with the rise of monomania, the American historian unravelled doctors' interest in diagnosing their patients with some form of obsession. By putting the accent on the cultural formation of an elusive disease, however, we might forget that, on many occasions, doctors and inmates were consumed by the same passion and devoured by the same idea. By emphasizing the development of professional practices, Goldstein might have lost sight of the fact that the truncated ambition that characterized monomaniacal patients was very similar to the professional ambition of their doctors. In this sense, the history of symptoms does not coincide with the history of diagnostic practices. In our case, the virtuous perseverance of the one (Leuret) was not much different from the vicious stubbornness of the other (Nicolas). Both were consumed by an irresistible passion. The two were inscribed in the context of the liberation from authority and the vindication of a program of self-government. Both wanted to leave the mud of mediocrity: 'the social vacuum in which the dark birth and poverty maintain so many superior minds', as Hequet put it. ${ }^{37}$ The difference does not lie, therefore, in the passion that governs their behaviours but in their different outcomes. The failure of the patient does not correspond to the success of the doctor, but that dissimilarity does not prevent a correspondence of feelings and ideas. Anyone who 
has read the collection of eulogies addressed to the members of the Academy of Medicine must also have noticed this striking similarity of sentiments. ${ }^{38}$ The spectacle of madness reached the point that Leuret himself admitted having seen in the universities and academies of France people greatly afflicted by delirium very similar to those he could find in the asylums of Paris. Although both sets of theories had developed from a small number of instances, he argued that it was only 'a matter of chance what has placed some of them in [the] asylum and others at the Universities, ${ }^{39}$

\section{The making of a clinical case}

One of Leuret's assistants, Pierre-Egiste Lisle, author of a memoir on the law of 1838 and a pamphlet on the social causes of suicide, published a different version of Nicolas's story, which, although very similar to that of Leuret, also contained some new elements. ${ }^{40}$ In Lisle's version, Monsieur Nicolas was called Adolphe. This man, Adolphe L., Lisle tells us, was admitted to Bicêtre on 21 July 1839, by order of the Prefecture of Police. The young assistant describes him as a cultivated person who attributed his situation to a diagnostic error. As in Leuret's version, Lisle echoes the previous imprudence of the inmate offering more details. Apparently, Adolphe had had himself locked up in the mental asylum of Dôle, in the Franche-Comté. It was there that he reached the rank of deputy director, probably after the transformation of the dêpot de méndicité (house of charity) and its division into two independent sections, one of which became the asylum for the mentally ill. Adolphe explained to Lisle that as a person with responsibilities, he had always treated the inmates with kindness, that he had never used force, intimidation or fear and that he had always tried to convince them of their errors without resorting to violence. According to Lisle, 'the inmate allowed himself to give us advice about how we should behave in relation to the unfortunates entrusted to our care'. ${ }^{41}$ He claimed he was not crazy, and to prove it he cited the authority of Élias Regnault, a lawyer who had been especially critical of all the alienists who had confused passions with madness.

Lisle's and Leuret's accounts share the same narrative structure, sometimes even the same words. Although both claimed to have directly witnessed Adolphe's delirium, the first version must have been that of Lisle, then a young resident working on a doctoral thesis on pharmacology. Adolphe would certainly have been subjected to cold showers, and his agitation, his mania, did not last long. On 25 July, after complaining about the violent and inhumane treatment he was undergoing, he seemed to have become 'calm and reasonable'. His moments of rest were progressively more frequent. After a few days, 


\section{Cultural History}

his temperament became sweet and kind, to the point that on 15 September he apologized to the assistant for a recent outburst of fury. According to Lisle, Adolphe was able to leave the hospice at the beginning of 1840, fully cured.

The story contains a few dramatic elements that in the history of psychiatry have served to explain how early nineteenth-century doctors read in the symptoms of their patients the clinical signs of a disease. The story is interesting not only because the protagonist was considered mad, or because he was allowed to leave the asylum once he apologized to the assistant. Maybe Nicolas was not a maniac after all. Maybe he only calmed down owing to the terror produced in him by the expectation of cold showers. Maybe he gave up. Maybe he lied. That at least is the opinion of Dr Esprit Sylvestre Blanche, for whom Leuret, far from producing genuine cures, had turned his medical practice into a manufacture of hypocrites. $^{42}$ Far from replacing one passion with another, patients renounced their delusional ideas out of fear. ${ }^{43}$ It was only by the use of pain and intimidation that the inmates came to recognize what they did not believe. The chief doctor of Bicêtre, Blanche argued, could equally have used sticks or an infinite number of other means described in the records of the Spanish Inquisition. If he had decided to burn the feet of his patients, for example, they would also have been forced to say: 'Yes, yes, I am crazy', or 'Yes, yes, I'm wrong. ${ }^{44}$

In this case at least, the dispute between doctor and patient regarding the status of Nicolas and his allegations of ill-treatment has not been resolved. Leuret's interpretation of the case only allows us to approach his narrative strategy but does not solve the problem, still open, of who this man really was who had himself locked up in Bicêtre in July 1839 and remained in the ward for the mentally ill, receiving cold showers, until leaving, perhaps humiliated and debased, in the early 1840s. The dispute between Leuret and Nicolas over the case will also have affected the future construction of their historical memory. From the point of view of the history of the experience, Leuret used Nicolas to prove the virtues of his new treatment. The publication of the case helped to establish his professional position. As in many other similar cases, the prisoner's living conditions became an essential part of a scientific dispute. Far from being at the patient's service, the doctor used the patient as evidence for his own therapeutic method. Not only did he identify the signs of a mania, but he was able to transform them into evidence for his own clinical school. In Leuret's hands, the story of the inmate seems to result from a fiery imagination. The young man says he has been betrayed, but it is not true; he says he has been abandoned, but it is not true; he says that he has been mistreated by the assistants, on whom he wishes death, 


\section{Ambition in Early Nineteenth-Century France}

but no one, Leuret tells us, would have been capable of causing him any harm. The inmate complains of humiliating and violent treatment. But none of that is true. None of that ever happened.

That Nicolas could have fabricated his own story undoubtedly had a decisive effect on the diagnosis and treatment. The details he gave regarding his past were not enough to convince the doctor, who, consequently, considered his patient's story, although told with credibility, to be a symptom of delirium. Leuret understood that the majority of his patients, unlike those alienées (mentally ill) who built their own worlds, took elements of reality and decorated it according to their interests and expectations. Far from living completely in a fictional world, they were arrangeurs, literally 'arrangers'. Monomaniacs, he explained, do not go so far as to create a world, but they mix their experiences with scattered elements ordered according to their expectations and desires. Their skills bestow fiction with an appearance of plausibility. ${ }^{45}$

\section{The archive}

The register of admissions to Bicêtre consists of enormous books in which a helpful hand added the names and dates of admission of newcomers, along with many other data. Along with the number and the full name of the inmates, the documentation collects, in a table, other information, such as the place of birth, age, marital status, profession, known address, and the order in virtue of which the institutionalization took place, as well as the economic status of the inmate, who could be either a pensioner or indigent. Among the causes of institutionalization, the register distinguished essentially two categories: alienation and epilepsy. Among the causes of alienation, we found abuse of alcohol, sorrows and discontents, deprivations of all kinds, indigence, passionate or emotional excesses, jealousy, masturbation and ageing. The records also indicate whether the inmate had been transferred to the indigent or incurable section, as well as the date of discharge or death. There is also a final column of observations with all types of comments related to medical or administrative history. At least during the 1830s, the inmates were simply divided into curable and incurable.

Between 1 June and 31 July 1839, the manuscript register of Bicêtre accounts for 117 new inmates. None of them was called Nicolas. Nor does anyone correspond to Adolphe L. On 21 July 1839 , the date on which this person entered Bicêtre according to Lisle, not a single new inmate was registered in Bicêtre. On alternative dates, the information provided by the registry may point to other cases compatible with the evidence described by Lisle. However, none of these cases is consistent with the rest of the data. That is, even if we assume the name provided by Lisle was 


\section{Cultural History}

false, neither age, profession, diagnosis, or the tentative date of discharge provided coincide with the records of a patient. In the period under consideration, two Adolphes were recorded. The first was a jeweller declared incurable. The other was returned to his mother.

The total registry for the entire population of Bicêtre for 1839 consists of twenty books distributed across different categories. After the law of 1838 replaced the entry and discharge system, there was an important modification to the way in which newcomers were accounted for. Before 1839 Nicolas, or Adolphe, could have been registered in different ways. The truth is, however, that he left no trace in the archives. There is not the slightest vestige of anyone with a compatible description, whether in age, profession, or approximate dates of entry or discharge, to the case described by Leuret and Lisle. Nor does the Dôle's Registry give any clue to a deputy director or other inmate whose description closely resembles that provided by these two doctors. In neither of these two institutions is there any trace of our patient. In the discharge records, there is no mention. There is no way to find him among those hospitalized, nor among the idiots, the insane or the destitute. Nor is this case mentioned in the correspondence. In all probability, his case was built, like that of a modern Prometheus, from fragments of the lives of others. Perhaps Leuret, like his patients, also had the habit of arranging the reality of his patients at will, so that it would fit better with his own wishes and expectations. Perhaps based on real events, the circumstances surrounding the medical history of the man who had himself locked up to punish the pride of his parents, who was considered mad, who swore revenge and asked for justice after having received cold showers, concern us as an expression of a melancholic form of memory.

There is at least one aspect in which Blanche was right: the way in which the alienated formed their reality did not differ much from the way in which some alienists created theirs. In both cases, we face stubborn stories supported by false information. Thus, while Leuret considered that Nicolas suffered from monomania of ambition, Blanche claimed that Leuret was afflicted with the same misfortune. Suffering from the disease of his own pride, motivated by an offended vanity, he had more interest in defending his person than his principles. ${ }^{46}$ The chief medical doctor of Bicêtre, argued Blanche, had never intended to be guided by evidence or driven by the truth. On the contrary, his attitude resembled that of all those who, consumed by vanity, had no other motivation for their actions than seeing their names inscribed in the Memoirs of the Academy. Far from putting his talent and life at the service of his patients, Leuret, continued Blanche, used them to nurture his pride and sustain his ambition. It is hard not to see in Guy de Maupassant's short story 


\section{Ambition in Early Nineteenth-Century France}

'Dr Heraclius Gloss' a caricature of this doctor who, after receiving 'the most horrible avalanche of cold water on the backs of a mortal, was calm, taking enormous care not to say a single word of what had been the cause of his misfortune'. ${ }^{47}$

\section{Conclusions}

When examining this same clinical history, the historian of medicine Juan Rigoli stops at the rhetorical forms used by Leuret to endow it with verisimilitude and narrative force. As we mentioned at the beginning of this article, he compares the doctor with the author of an opera libretto, seeking to convince the reader of the reality of the events described in the medical history and interested in producing the illusion of being a direct witness of an interrogation. The study of these narrative strategies, as well as of the way in which doctors identified the signs of illness in the facial features, physical gestures or words of the inmate, forms a rhetorical space from which escape seems rather impossible. The spectacle of madness allows us to understand the medicalization of passions: the transformation of emotional symptoms into clinical signs. Rigoli seems to forget, however, that the story of Nicolas includes a dispute over the hegemonic story and exemplifies a conflict between doctor and patient. ${ }^{48}$ The story of Nicolas, 'his story', happens not only when the doctor reproduces his words but also at the time of the first interview between the two. Before his expressive symptoms became clinical signs, before his passions were medicalized and fixed, before Leuret could interpret his gestures, his words and his cries, and before historians of psychiatry of the twentieth or twenty-first century could analyse their rhetorical elements, there is a space of underdetermination in which the inmate's story lacks any kind of clinical significance. It is not the history of psychiatry but the history of emotions. It is not the spectacle of madness but the mere expression of vehement passions. In this comedy, obsessions get mixed with reasons, and hallucinations with realities. Patients and doctors share the same prejudices and behave according to the same principles. The history of psychiatry has reflected a lot on the delusions of the alienated, on their errors of conception or judgement, and much less on the hallucinatory character of the diagnosis, on the way in which the collected evidence, histories and clinical cases served as raw material for the elaboration of theoretical treatises or therapeutic practices.

Since Lucien Febvre's now-famous paper on the history of emotions, the advantages and uses of history for present-day life, to use Friedrich Nietzsche's expression, have become increasingly pressing. In a notorious final paragraph, the French historian advocated for a new 


\section{Cultural History}

form of history that would, eventually, emerge from this psychological approach: a history understood as a connection between ancient and new; a history viewed as 'our own history, a perpetual sentimental history of resurgences and resurrections'. ${ }^{49}$ This connection between the history of the emotions and the political dimension of history has also been underlined by other authors. ${ }^{50}$ Beneath the known history of Europe, wrote Max Horkheimer and Theodor Adorno in a rarely quoted passage of their Dialectic of Enlightenment, 'there runs a subterranean history that consists of the fate of human instincts and passions repressed and distorted by civilization. ${ }^{51}$ Despite all its limitations, the history of emotions, or, as I prefer to call it, the history of experiences, can help us to uncover those subterranean stories that seem to lack the appearance of truth. As the story of Nicolas comes to suggest, the history of emotions cannot be separated from their dramatic representations. On the contrary, the spectacle of madness appeals to the rhetorical conditions that makes it possible. If emotions are, as Monique Sheer has shown, a kind of practice, their study will have to rely on their performative nature and, even before that, on the dramatic strategies that may have turned them into a medical condition. ${ }^{52}$

\section{Notes}

1. This article was written with the support of a research grant provided by the Spanish Ministry of Science: Research Project FFI2016-78285-R.

2. On Charenton, see Charles Strauss, La Maison national de Charenton (Paris: Imp. National, 1900), pp. 219-26; Max Ferré, Charenton-le-pont: D'hier à aujourd'hui (Paris: Éditions d'art les heures claires, 1971); Edmond Auguste Texier, Les Grands asiles d'aliénés de Paris au milieu du siècle: La Salpêtrière, Bicêtre, Charenton (Paris: L. Pariente, 1978); Jean-Étienne-Dominique Esquirol, Mémoire historique et statistique sur la Maison Royale de Charenton (Paris: Paul Renouard, 1835); Charles-François Giraudy, Mémoire sur la maison de Santé de Charenton, (Paris:Société de Médecine, 1804); Alexandre Brierre de Boismont, 'Mémoire pour l'établissement d'un hospice de l'aliénés', Annales d'hygiène publique et de médecine légale, 16 (1836), pp. 39-120; Marcel Gauchet and Gladys Swain, La pratique de l'esprit humain: L'institution asilaire et la révolution démocratique (Paris: Gallimard, 1980); Pierre Pinon, L'hospice de Charenton (Liège: Mardaga, 1989); and Jean-Philippe Gaussens, Histoire institutionnelle de la Maison de Charenton (Rennes, École nationale de la santé publique, 1978).

3. Paul Bru, Histoire de Bicêtre (Hospice, Prison, Asile) (Paris: Aux bureaux du progrès, 1890), pp. 263-4.

4. Esquirol, Mémoire historique, pp. 45-6. See also Sade, Journal inédit (1807, 1808, 1814): Deux cahiers retrouvés, publiés sur les manuscrits autographes inédits suivis d'une Notice sur l'hospice de Charenton par Hippolyte de Colins (Paris: Gallimard, 1994). On these spectacles, see Antoine Ritti, 'Le spectacle chez les aliénés', Annales médico-psychologiques, no. 3 (November/December 1898).

5. Sade, Journal inédit, p. 146.

6. Alexandre Auguste Millet, Coup de œil historique et médical sur Bicêtre (Paris: Didot Jeune, 1842). 


\section{Ambition in Early Nineteenth-Century France}

7. Jean-Étienne-Dominique Esquirol, Des maladies mentales, considérées sous le rapports médical, hygiénique et médico-légal, accompagnées de 27 planches gravées, vol. 2 (Paris: J. B. Billière, 1838), p. 70.

8. François Leuret, 'Observations d'un cas de sentiment musical très développé chez une idiote', in Désiré Magloire Bourneville, ed., Recueil de mémoires, notes et observations sur l'idiote (Paris: Progrès Medical, 1891), pp. 399-404.

9. Marc Auberthie-Lamalethie, Dissertation sur la médecine de l'esprit (Paris: Didot jeune, 1808), p. 20.

10. Victor Turner, From Ritual to Theatre: The Human Seriousness of Play (New York: PAJ Publications, 1982); Victor Turner, The Ritual Process (Chicago: Aldine, 1995); and Michael Fried, Absorption and Theatricality: Painting and Beholder in the Age of Diderot (Berkeley: University of California Press, 1980).

11. For the concrete case of the contemplation of harm, see Jacques Rancière, The Emancipated Spectator, Gregory Elliott (transl.) (London: Verso, 2009).

12. Juan Rigoli, Lire le délire: Aliénisme, rhétorique et littérature en France au XIX siècle (Paris: Fayard, 2001), pp. 306-9.

13. François Leuret, Des indications à suivre dans le traitement moral de la folie (Paris: Le Normant, 1846).

14. For a much larger account of this clinical case, see my Promesas incumplicas: Una historia política de las pasiones (Madrid: Taurus, 2017).

15. Leuret, Des indications, p. 35.

16. Alexis de Tocqueville, L'ancien régime et la Révolution (1856; Paris: Garnier, 1952), p. 84. See Albert O. Hirschman, The Passions and the Interests: Political Arguments for Capitalism before its Triumph (1973; Princeton, NJ: Princeton University Press, 2013). For the case of 'glory', see Robert Morrissey, The Economy of Glory: From Ancien Régime France to the Fall of Napoleon (Chicago, IL: University of Chicago Press, 2010).

17. Jay M. Smith, The Culture of Merit: Nobility, Royal Service, and the Making of Absolute Monarchy in France, 1600-1789 (Ann Arbor: University of Michigan Press, 1996), p. 44, cited by Kathleen Kete, Making Way for Genius: The Aspiring Self in France from the Old Regime to the New (New Haven, CT: Yale University Press, 2012), p. 3.

18. François-René de Chateaubriand, Memorias de ultratumba (1849-50), José Ramón Monreal (transl.), vol. 1 (Barcelona: Acantilado, 2006), p. 181. On ambition, see William Casey King, Ambition, a History: From Vice to Virtue (New Haven, CT: Yale University Press, 2013), p. 2.

19. Germaine de Staël, [1796], De l'influence des passions sur le bonheur des individus et des nations, suivi de [1813], Réflexions sur le suicide, Paris: Rivages Poche, 2000, p. 106.

20. Jean-Louis Alibert, Physiologie des passions, vol. 1 (Paris: Béchet, 1825), pp. 330-1.

21. Etienne Tourtelle, Élémens d'hygiène, ou de l'influence des choses physiques et morales sur l'homme, et des moyens de conserver la santé, vol. 2 (Paris: Rémon, 1823), p. 523.

22. Alexis de Tocqueville [1835-1840], De la démocratie en Amérique (Paris: Flammarion, 1981, vol. 2, p. 119.

23. Augustin Barruel, Mémoires pour servir à l'histoire du Jacobinisme, vol. 1 (1800; s.l.: Elibron Classics, 2005), p. 332.

24. Marie-Jean Hérault de Séchelles, Théorie de l'ambition (1788; Paris: Bouquet, 1802), p. 1.

25. The political history of psychiatry, exemplified in the work of Laure Murat's L'homme qui se prenait pour Napoléon, (Paris: Gallimard, 2011) could have not been written without this expert acknowledgement of the moral and political causes of madness.

26. Alibert, Physiologie des passions, p. 331. 


\section{Cultural History}

27. On monomania, see Jan Goldstein, Console and Classify: The French Psychiatric Profession in the Nineteenth Century (New York: Cambridge University Press, 1987), p. 154: See also Lennard J. Davis, Obsession (Chicago, IL: University of Chicago Press, 2008), pp. 69-70.

28. Régistres d'observations médicales de Charenton, Registres d'observations médicales hommes et femmes, Série X4 691, 1812-44. Paris: Archives départementales du Val-de-Marne, Créteil. Histoire 43.

29. Ibid. Histoire 14.

30. Ibid. Histoire 68.

31. F. E. Foderé, Voyage aux Alpes maritimes, vol. 2 (Paris: Levraut, 1821), p. 155.

32. Jean-Marie-Placide Munaret, Du médecin des villes et du médecin de campagne: Mours et science (Paris: Germer Baillière, 1840), pp. 25-6.

33. Esquirol, Des passions considérées comme causes, symptômes et moyens curatifs de l'aliénation mentale (Paris, 1805), p. 14.

34. Charles Hequet, Notice biographique sur la vie et les travaux du docteur Leuret (Nancy: Grimblot et Veuve Raybois, 1852), p. 5.

35. Ulysse Trélat, Notice sur François Leuret (Paris: Baillièr, 1851), p. 5.

36. Jan Goldstein, Console and Classify : The French Psychiatric Profession in the Nineteenth Century (New York: Cambridge University Press, 1987)

37. Hequet, Notice biographique, pp. 5-6.

38. Félix Vicq d'Azyr, Éloges historiques, Édition réunie par Jacques L. Moreau de la Sarthe Paris (Paris: Duprat-Duverger, 1805). See also Frédéric Charbonneau, 'L'apothéose médical, de Fontenelle à Vicq d'Azir', in Frédéric Charbonneau (ed.), La Fabrique de la modernité scientifique: Discours et récis du progrès sous l'Ancien Régime (Oxford: Voltaire Foundation, 2015), pp. 129-48.

39. François Leuret, Fragments psychologiques sur la folie (Paris: Crochard, 1834), p. 42.

40. Pierre-Egiste Lisle, 'Leçons cliniques sur les maladies mentales, professées par M. Leuret (Recueillies et rédigées par m. Lisle, ancient élève des hôpitaux), in Encyclographie des sciences médicales, Bulletin médical belge, 121:7 (1840), pp. 369-70.

41. Ibid. p. 369.

42. Esprit Sylvestre Blanche, Du danger des rigueurs corporelles dans le traitement de la folie, vol. 4 (Paris: Académie Royale de Médecine, 1839), pp. 79-81. On Blanche, see Laure Murat, La maison du docteur Blanche (Paris: 2001).

43. Esprit Sylvestre Blanche, De l'état actuel du traitement de la folie (à propos du dernier ouvrage de M. Leuret) (Paris: Gardembas, 1840), p. 59.

44. Ibid. p. 58.

45. Leuret, Fragments psychologiques, p. 47: 'L'arrangeur ... se trompe sur des choses où le bon sens suffit. Souvent l'arrangeur est habile: il donne avec un talent particulier une apparence de réalité à ses conceptions. Pour prouver ce qu'il a dans l'esprit tout lui sert: il n'est dissuadé ni embarrassé par aucune preuve contradictoire.'

46. Blanche, Du traitement de la folie, p. 30.

47. Guy de Maupassant, 'Le docteur Héraclius Gloss', in La Horla et autres contes d'angoisse (Paris: Flammarion, 1984), pp. 132-3.

48. Rigoli, Lire le délire. On this case, see pp. 306-9.

49. Lucien Febvre, 'Sensibility and History: How to Write the Emotional Life of the Past', in Peter Burke (ed.), A New Kind of History from the Writings of Lucien Febvre (London: Routledge and Kegan Paul, 1973), pp. 12-26 (26).

50. Ruth Leys, 'The Turn to Affect: A Critique', Critical Inquiry, 37:3 (May 2011), pp. 434-72 (437). 


\section{Ambition in Early Nineteenth-Century France}

51. Theodor W. Adorno and Max Horkheimer, Dialektik der Aufklärung, in Adorno, Gesammelte Schriften, vol. 3 (Frankfurt am Main: Suhrkamp Taschenbuch Wissenschaft, 1997), p. 265.

52. Monique Sheer, 'Are Emotions a Kind of Practice (and is That What Makes them Have a History)? A Bourdieuian Approach to Understanding Emotion', History and Theory, 51:2 (2012), pp. 193-220. 